\title{
GREATEST HAPPINESS FOR THE GREATEST NUMBER
}

\author{
Ruut Veenhoven
}

In: Alex C. Michalos (Ed.) Encyclopedia of Quality of Life and Well-Being Research Springer, Dordrecht, Netherlands, 2014. Springer Reference Series, pp. 2612-2613. ISBN 978-94-007-0752-8

DOI: 10.1007/978-94-007-0753-5_3903

\section{SYNONYMS}

Greatest happiness principle

\section{DEFINITION}

The greatest happiness principle is a moral tenet, which holds that the best thing to do is what contributes to the greatest happiness of the greatest number of people.

\section{DESCRIPTION}

\subsection{History of the idea}

During the Middle Ages, it was widely believed that happiness is not possible in earthly life and that the basis of morality was in the word of God. These views were contested in the "Enlightenment"; happiness came to be seen as attainable, and morality was regarded as man-made. A lively discussion on the relation between happiness and morality emerged, and in this climate, an instrumental view on morality appeared, in which ethical codes are seen as ways of securing a happy life.

Much of this enlightened thought is reflected in Jeremy Bentham's (1907) "Introduction to morals and legislation." Bentham argues that the moral quality of an action should be judged by its consequences on human happiness, and in that line, he claims that we should aim at the "greatest happiness for the greatest number." Bentham defined happiness in terms of psychological experience, as "the sum of pleasures and pains." His philosophy is known as " utilitarianism," because of its emphasis on the utility of behavioral consequences. "Happyism" would have been a better name, since this utility is seen as a contribution to happiness.

\subsection{Variants of the idea}

When applied at the level of individual choice (act-utilitarianism), this tenet runs into some difficulties. One problem is that often one cannot foresee what the balance of effects on happiness will be. Another problem is that the principle deems well-intended behavior to be immoral if it happens to pan out adversely. Imagine the case of a loving mother who saves the life of her sick child, a child that grows 
up to be a criminal; mothers can seldom foresee a child's future and can hardly be reproached for their unconditional mother's love.

The principle is better suited for judging general rules, such as the rule that mothers should care for their sick children. It is fairly evident that adherence to this rule will add to the happiness of a great number. Following such rules is then morally correct, even if consequences might be negative in a particular case. This variant is known as "rule utilitarianism."

When applied to public policy, the principle is also called "political utilitarianism" and holds that institutions, laws, and social policy should maximize happiness. Bentham used the greatest happiness principle in that way and discussed the implications of that principle for property laws and the death penalty. Interest in such applications is rising these days. For example, Layard (2005) pleas on this ground for higher income tax and more investment in mental health care.

In political utilitarianism, the focus is typically on average happiness. One can also give priority to the happiness of the least happy (negative utilitarianism) or to reducing inequality in happiness (egalitarian utilitarianism). An empirical analysis by Ott (2005) suggests that most social policies fit all these principles equally well.

\subsection{Reception of the idea}

This secular ideology has met considerable resistance. In the eighteenth century, the opposition came mainly from the churches, which were still quite powerful in those days. In the nineteenth century, there was also opposition from the liberal and socialist emancipation movements that were more interested in freedom and equality than in happiness. In the early twentieth century, considerable opposition came from the then- virulent nationalism that laid more emphasis on the glory of the nation than on the happiness of its inhabitants.

All these ideologies lost power in the late twentieth century, and partly for this reason, Bentham's greatest happiness principle made a comeback. The recent emergence of quality of life research is part of this longterm ideological shift.

\subsection{Objections of the idea}

The ideological opposition against the greatest happiness principle gave rise to several intellectual arguments, in particular against political utilitarianism. Some of the objections draw on assumptions about reality and can be checked empirically. One of these arguments is that "great happiness" is hardly possible in the human condition and that "greater happiness" is fully out of reach. Another argument holds that attempts to further happiness will bring us from the frying pan into the fire because of the various negative side effects of happiness and its pursuit. Many of these qualms figure in Huxley's (1932) famous science fiction novel "Brave New World," which described a society where people are happy subjectively, but miserable from an objective point of view.

The available data show that the principle is feasible; happiness of a great number is possible in contemporary conditions, and it is also possible to create more of it. The data also show that the promotion of happiness fits well with other ideals; happiness requires conditions that we value, such as freedom, and happiness fosters matters that we value, such as good health and civil behavior. Though 
happiness can conflict with these values in theory, it appears to match them in practice Veenhoven (2011).

\section{Cross-Reference in Encyclopedia of:}

Inequality-Adjusted Happiness

Happiness 


\section{References}

Bentham, J. (1907)

Introduction to the principles of morals and legislation.

London: Oxford Clarendon press.

Huxley, A. (1932)

Brave new world.

Stockholm: Continental Book.

Layard, R. (2005)

Happiness: Lessons from a new science.

New York: Penguin.

Ott, J. C. (2005)

Level and equality of happiness in nations: Does greater happiness of a greater number imply greater inequality in happiness?

Journal of Happiness Studies, 6, 397-420.

Veenhoven, R. (2011)

Greater happiness for a greater number: Is that possible and desirable?

Journal of Happiness Studies, 11, 605-629. 